Д-р техн. наук I.Е. Мартинов, acn. В.О. Шовкун

Doct. of techn. sciences I.E. Martinov, postgraduate V.A. Shovkun

\title{
ДОСЛІДЖЕННЯ НАПРУЖЕНО-ДЕФОРМОВАНОГО СТАНУ ЕЛЕМЕНТІВ БУКСОВИХ ПІДШИПНИКОВИХ ВУЗЛІВ
}

\section{RESEARCH THE STRESSED-DEFORMED STATE OF ELEMENTS OF THE AXLE BOX BEARING UNITS}

Вступ. Залізничний транспорт $\epsilon$ важливою галуззю народного господарства України, тому забезпечення безпеки руху поїздів $\epsilon$ важливим завданням. Одним 3 найважливіших резервів підвищення ефективності залізничного транспорту $\epsilon$ зниження тривалості простою вантажних вагонів у позаплановому ремонті. Однак, як показує практика експлуатації, незважаючи на постійне вдосконалення системи технічного обслуговування i ремонту, значна частина життєвого циклу вантажних вагонів витрачається на непродуктивне перебування в ремонтах різних видів. 3 аналізу причин надходження вантажних вагонів під позаплановий ремонт видно, що однією 3 основних $€$ відмова різних елементів буксового вузла. Підшипники працюють у складних умовах. Навіть при досить якісному виготовленні підшипників їх характеристики можуть виявитися незадовільними і станеться раптова відмова. Причиною цього може бути неякісний монтаж, неправильна експлуатація i т. п. Крім того, для підшипників, застосовуваних у буксах рухомого складу залізниць, критеріями відмови можуть бути зростання температури вище допустимих значень, розрив сепаратора, викликаний силами його взаємодії 3 тілами кочення, втомне вищерблення доріжок кочення, бічних поверхонь роликів, зношування торців роликів і робочих поверхонь бортиків кілець, відколи бортиків під дією імпульсного осьового навантаження. Забезпечення довговічності підшипника, що працює в умовах динамічного радіального i осьового навантаження, $\epsilon$ досить складним завданням. У зв'язку з цим у практиці i теорії вагонобудування як раніше, так і зараз актуальною $є$ проблема удосконалення буксових вузлів вантажних вагонів.

Постановка проблеми. Очевидно, що питання підвищення надійності буксових вузлів $\epsilon$ складним i вимагає комплексного підходу для свого вирішення. Тому необхідно досліджувати різні напрямки удосконалення існуючих та створення нових конструкцій буксового вузла. Одним 3 шляхів підвищення показників надійності буксових вузлів $\epsilon$ покращення конструкції корпусів букс.

Аналіз попередніх досліджень. Аналізуючи попередні роботи в цьому напрямку [3-5], можна зробити висновок, що методи розрахунку надійності та довговічності буксових вузлів $\epsilon$ застарілими i не повністю враховують імовірнісну природу дії навантажень, прикладених до елементів буксового підшипникового вузла.

При розрахунку на міцність елементів конструкції буксових вузлів використовуються спрощені схеми, які не 
враховують ряд діючих чинників, тому потрібен більш детальний аналіз розподілення навантажень між роликами 3 урахуванням можливостей сучасної обчислювальної техніки. Недосконалість існуючих методів розрахунку призвела до значних похибок при визначенні показників довговічності та надійності буксових підшипникових вузлів i розбіжності 3 фактичними результатами експлуатації.

Мета роботи. Вивчення впливу конструкції корпусу буксового вузла на характер розподілу радіальних навантажень між роликами підшипника. При моделюванні розглядається вплив тільки радіальних навантажень.

3 метою дослідження напруженодеформованого стану буксового вузла та вдосконалення методик розрахунку надійності і довговічності буксових вузлів у програмному середовищі ANSYS Mechanical APDL розроблено комп'ютерну 3D модель буксового підшипникового вузла вантажного вагона, яка включає модель корпусу букси, і модель здвоєного касетного підшипника 3 короткими циліндричними роликами (рис. 1).
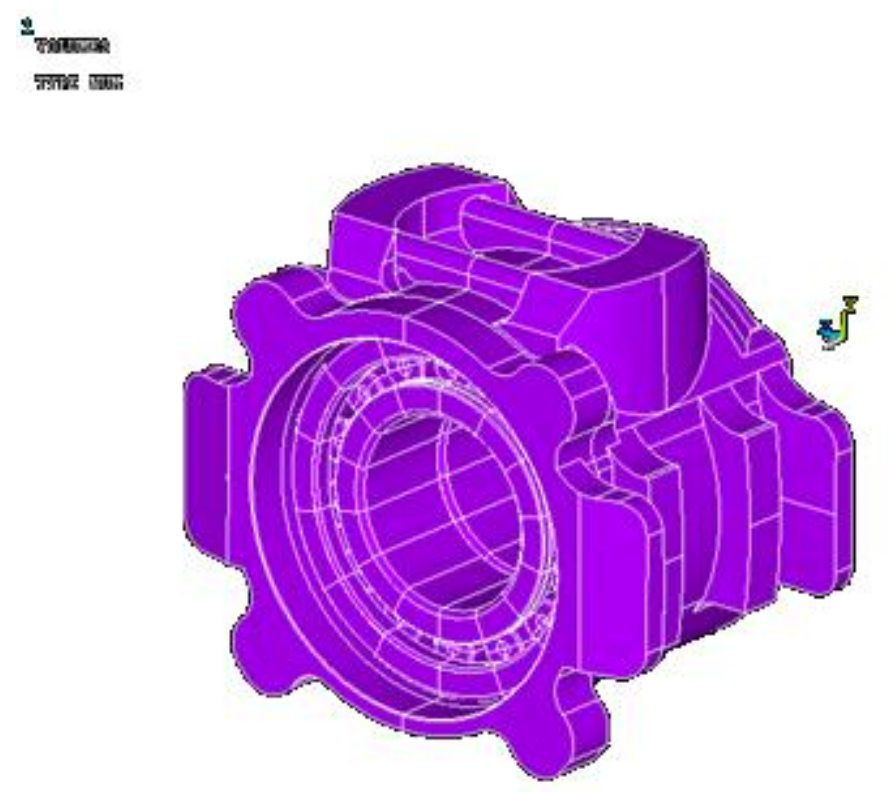

Рис. 1. Геометрична модель буксового вузла

Наявність сепаратора не впливає на розподіл контактних навантажень роликів і кілець. Тому замість нього для утримання роликів на певній відстані один від одного були введені спеціальні зв'язки, які моделюються за допомогою елементів Link11 - аналог пружини, працюючий на розтягнення та стиснення.

Для моделювання об'ємів твердих тіл використовувалися 10-вузлові скінченні елементи тетраедрального типу Solid92.
Елемент визначається десятьма вузлами, що мають три ступені свободи в кожному вузлі: переміщення у напрямі осей $\mathrm{X}, \mathrm{Y}, \mathrm{Z}$ в системі координат вузла. Саме такі елементи найкраще підходять для моделювання машинобудівних конструкцій відносно малих розмірів, але складної форми.

Розроблена скінченно-елемента модель складається 3360529 скінченних елементів та 1102726 вузлів (рис. 2). 


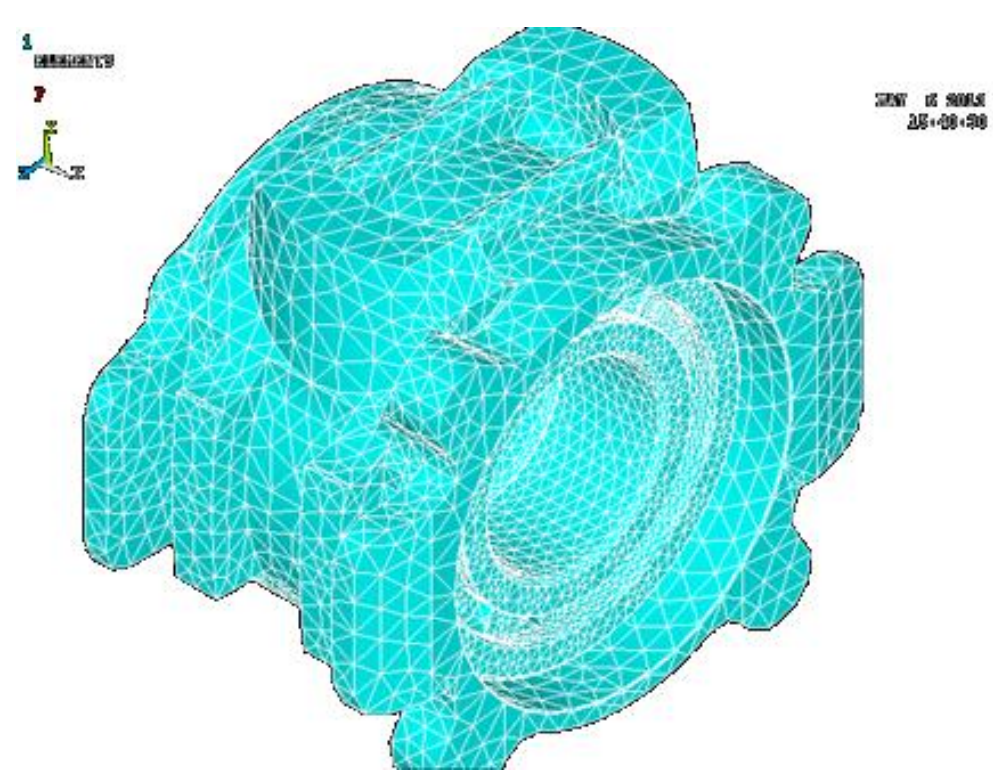

Рис. 2. Скінченно-елемента модель буксового вузла

Розмір сітки скінчених елементів у зоні контакту ролика та доріжок кілець уточнювався до розміру 0.02 мм, така особливість скінченно-елементної сітки дозволила 3 більшою точністю обчислити контактні напруження в зоні контакту та визначити характер розподілення напружень уздовж утворюючої роликів.

Для моделювання контактної поверхні роликів використовувалися скінченні елементи Targe 170, для контактної поверхні зовнішнього та внутрішнього кілець підшипника використовувалися скінченні елементи Konta174.

Контактні елементи мають ті самі геометричні розміри та загальний набір геометричних характеристик, що і пов'язані 3 ними реальні об'ємні елементи. ANSYS створює два різні типи контактних елементів: «цільові» на поверхні, яка має більшу жорсткість (у нашому випадку це ролики). Ці елементи вдавлюються в «контактну» поверхню, яка має меншу жорсткість (поверхні кочення зовнішнього та внутрішнього кілець).

Під час створення моделі були прийняті такі допущення, що відповідають основним положенням теорії Герца:
- навантаження до контактуючих поверхонь прикладене перпендикулярно до площадки контакту;

- область контакту мала порівняно 3 радіусами кривизни контактуючих тіл;

- матеріали контактуючих тіл однорідні, ізотропні та ідеально пружні;

- вплив технологічних відхилень при складанні елементів ходових частин на навантаження елементів підшипника, а також їх можливе спрацювання в експлуатації не враховуються;

- вплив мастила на контактну міцність деталей підшипника не враховується.

При розрахунку буксового вузла були прийняті такі допущення: матеріал буксового вузла працює в пружній стадії деформації і має постійні характеристики модуль пружності сталі, з якої виготовлені кільця підшипника, приймався рівним $2,1 \times 10^{11}$ Па, коефіцієнт Пуассона 0,3 ;

- модуль пружності сталі, 3 якої виготовлений методом лиття корпус букси, приймався рівним $1,8 \times 10^{11}$ Па, коефіцієнт Пуассона 0,25 ;

- модель враховує не лише внутрішню геометрію підшипників, але й особливості передачі навантаження на них, а також 
дозволяе імітувати різні варіанти навантаження 3 оцінкою напруженодеформованого стану як самого підшипника, так i інших елементів буксового підшипникового вузла.

- вертикальне навантаження розраховувалося виходячи 3 величини максимально можливого навантаження на вісь 230 кН. При розрахунках враховувався найбільш несприятливий варіант завантаження корпусу (з урахуванням коефіцієнта вертикальної динаміки).

Вертикальне навантаження моделювалося шляхом прикладення сили у вузлах, у верхніх приливах корпусу букси, діючої у напрямку осі «Y0».

Аналіз отриманих результатів. При розв'язанні в програмному комплексі Ansys були отримані максимальні контактні напруження, виникаючі в зоні контакту ролика i доріжок кілець підшипників, a також епюри розподілу радіальних зусиль на ролику в процесі обертання.

Очевидно, що в зоні контакту тіл кочення 3 зовнішнім кільцем найбільші напруження мають місце в зоні центрального (першого) ролика. У той же час у зоні контакту роликів 3 внутрішнім кільцем максимальні напруження досягаються в зоні наступного (другого) ролика.
Аналізуючи епюри розподілу напружень між роликами, можна сказати, що:

- кут навантаженого сектора становить $105^{\circ}$;

- ролик, проходячи повний оберт, сприймає два піки навантаження;

- максимальні контактні напруження, виникаючі в найбільш завантаженому ролику, становлять 899 МПа.

Встановлено, що величина напружень мінімальна посередині ролика та збільшується до максимальних значень у зоні переходу від утворюючої ролика до його торця (тобто має місце так званий "крайковий" ефект).

\section{Висновки.}

Математичне моделювання показало, що зусилля, сприймане роликами підшипників, а отже, їх довговічність істотно залежать від конструкції корпусу букси. Визначено, що контактні напруження уздовж утворюючої ролика, як $\mathrm{i}$ розподілення радіальних зусиль, не є рівномірним, а тому викликає декілька піків навантаження, що в свою чергу негативно впливає на довговічність підшипника. Виходячи 3 аналізу результатів моделювання можна зробити висновок, що конструкція корпусу буксового вузла не $\epsilon$ задовільною і тому потребує подальшого доопрацювання.

\section{Сиисок літератури}

1. Перель, Л.Я. Подшипники качения: Расчет, проектирование и обслуживание опор [Текст]: справочник / Л.Я. Перель. - М., 1983. - 543 с.

2. Басов, К.А. ANSYS [Текст]: справочник пользователя/ К.А. Басов. - М.: ДМК Пресс, 2011. $-640 \mathrm{c}$.

3. Мартинов, I.Е. Дослідження напруженого стану конічних роликопідшипників [Текст] / I.Е. Мартинов // Зб. наук. праць. - Харків: УкрДАЗТ, 2007. - Вип. 81. - С. 83-86.

4. Морчиладзе, И.Г. Совершенствование и модернизация буксовых узлов грузовых вагонов [Текст] / И.Г. Морчиладзе, А.М. Соколов // Железные дороги мира. - 2006. - № 10. C. 59-64.

5. Слушкин, И.В. Разработка рациональных конструкций корпусов букс подвижного состава на роликовых подшипниках [Текст] / И.В. Слушкин // Вопросы перевода подвижного состава на роликовые подшипники: труды ВНИИЖТ. - М.: Транспорт, 1961. - Вып. 221. C. 110-136. 
Ключові слова: буксовий вузол, напружено-деформований стан, контактні напруження.

\section{Анотаціï}

Розглянуто питання вдосконалення буксових вузлів вантажних вагонів, побудовано комп'ютерну модель буксового вузла вантажного вагона. Проведено комп'ютерний аналіз напружено-деформованого стану буксового вузла. Отримано епюри розподілу контактних напружень уздовж утворюючої ролика, а також розподілення радіальних зусиль між роликами підшипника.

Рассмотрены вопросы совершенствования буксовых узлов грузовых вагонов, построена компьютерная модель буксового узла вагона. Выполнен компьютерный анализ напряженнодеформированного состояния буксового подшипникового узла. Получены эпюры распределения контактных напряжений, а также распределения радиальных усилий между роликами подшипника.

Considered are the issues of improvement of bearing units of freight cars, built a computer model of the bearing unit of the car. Made computer analysis of the stress-strain state of the bearing arrangement. Received plots of the distribution of contact stresses, as well as, the distribution of radial forces between the roller bearing. 